\title{
Малоконтактний багатоплоцинний остеосинтез діафізарних переломів кісток гомілки
}

\author{
P. I. BILINSKYI \\ National Medical Academy of Postgraduate Education by P. L. Shupyk
}

\section{LIMITED CONTACT MULTIPLANE OSTEOSYNTHESIS OF DIAPHYSEAL SHINBONE FRACTURES}

\begin{abstract}
На основі системного підходу, концептуального обгрунтування, теоретичних методів математичного і комп’ютерного моделювання розроблено нову методику малоконтактного багатоплощинного остеосинтезу діафізарних переломів кісток гомілки та засіб для ії реалізації. Проведено порівняльне дослідження фіксуючих можливостей розробленого фіксатора і повноконтактної пластини за допомогою методу кінцевих елементів. Досліджено напружено-деформаційний стан системи “фіксатор-кістка” різних способів фіксації переломів кісток гомілки.

Отримано теоретичні дані про величину мікрорухомості відламків, залежно від характеру лінії перелому, величини прикладеної сили, конструктивних особливостей фіксатора. Вивчено стан напруження пластин, його залежність від конструкції фіксатора, особливостей перелому, величини навантаження. Досліджено значення репозиційної стабілізації фрагментів гвинтами косих і скалкових переломів кісток гомілки на жорсткість фіксації, мікрорухомість відламків, напруження елементів конструкції фіксаторів, кісткових фрагментів.

Побудовано концепцію малоконтактного багатоплощинного остеосинтезу діафізарних переломів кісток гомілки, опрацьовано методику її реалізації. На основі цієї концепції, даних теоретичного дослідження величини мікрорухомості відламків, напруження елементів конструкції фіксаторів, кісткових фрагментів залежно від характеру лінії перелому розроблено нові методики хірургічного лікування переломів кісток гомілки оригінальним фіксатором. Прооперовано та проведено аналіз результатів лікування 90 пацієнтів із різноманітними діафізарними переломами кісток гомілки.

On the base of systemic approach, conceptual substantiation, theoretic methods of mathematic and computer modelling a new method of limited contact multiplane osteosynthesis of diaphyseal shinbone fractures (SBF) and device for its realization were developed. Comparative analysis of fixing capabilities of the developed device and full-contact plate was performed by means of finite element method. Stress-strain state of the "fixative-bone" system of different fixation methods of SBF was investigated.

Theoretic data about the size of the micromobility of bone fragments depending on the fracture line pattern, imposed force, specific features of the fixative construction were obtained. Stressed state of plates, its dependence from fixative construction, fracture pattern, load size was studied. Influence of reposition stabilization of fragments by screws in oblique and comminuted fractures on fixation rigidity, micromotion of fragments, stress of fixative construction elements and bone fragments was investigated.

Conception of limited contact multiplane osteosynthesis of diaphyseal SBF was developed, technique of its realization was worked out. On the base of this conception, data of theoretical study of the size of fragment micromotion, stress of fixative construction elements, bone fragments depending on the fracture line pattern new methods of surgical treatment of SBF by means of the original fixative were developed. The 90 patients with different diaphyseal SBF were operated on and their treatment results were analyzed.
\end{abstract}

Постановка проблеми і аналіз останніх досліджень та публікацій. Одними із найпоширеніших ушкоджень опорно-рухового апарату є переломи кісток гомілки (ПКГ). У структурі скелетної травми вони складають від 15,2 до 36,6 \% всіх переломів довгих кісток [6, 14].

Час непрацездатності в середньому сягає 5-9 місяців $[8,9]$. Удосконалення засобів для остеосинтезу не привело до значного скорочення тривалості лікування, у 22-45 \% випадків спостерігаються незадовільні результати $[5,10]$.
Ефективне лікуванняПКГ можливе на основі глибокого знання біології кістки, процесу зрощення фрагментів, біомеханіки взаємодій “фіксатор- кістка”, $з$ позицій системного підходу [3, 12]. Фіксатор повинен допускати в кістці адекватне напруження. Загалом еластичність фіксатора повинна наближатися до еластичності кістки $[1,7]$. Цим умовам відповідають мостовина, подвійно-деротаційна пластини, малоконтактні багатоплощинні фіксатори. Більшість внутрішніх фіксаторів блокує передачу напруження в зоні контакту відламків $[2,4,13]$. 
Виникає потреба у розробці нової концепції остеосинтезу ПКГ, пристрою для її реалізації з мінімальним негативним впливом на фрагменти. Важливо вивчити величину мікрорухомості відламків (MPB), яку допускатиме цей фіксатор, порівняно з контактною накістковою пластиною (НП), а також величину напруження фіксаторів і фрагментів кістки після остеосинтезу.

Мета роботи: теоретично обгрунтувати та оптимізувати методику малоконтактного багатоплощинного остеосинтезу (МБО) діафізарних переломів кісток гомілки.

Матеріали і методи. На основі системного підходу проведено аналіз взаємодії елементів при повному контакті пластини 3 кісткою і його відсутності, простежено наслідки цієї взаємодії, вплив на репаративну регенерацію (РР). Визначено основні вимоги до конструкції фіксатора для забезпечення оптимальних умов зрощення фрагментів при ПКГ. Використовуючи теоретичні закони будівельної механіки, сформульовано вимоги до просторового розташування шурупів, доведено перевагу багатоплощинної стабілізації фрагментів.

Це, а також аналіз фіксації контактними пластинами, послужило основою для розробки концепції МБО ПКГ, яка передбачає стабілізацію переломів фіксаторами мінімального об'єму і довжини, що забезпечують вибір найбільш оптимальної конструкції для конкретної лінії зламу, а також місця встановлення відповідно до анатомічних особливостей пошкодженого сегмента; відновлення його несучої здатності, осі кістки відбувається після репозиції фрагментів, при відсутності тиску на кістку, багатоплощинному проведенні фіксуючих гвинтів, наявності елементу взаємодії їх із фіксатором, що створює із фрагментами біомеханічну конструкцію “фіксатор-кістка”, дозволяє програмувати величину МРВ, оптимізувати перебіг РР.

При розробці пристрою для проведення МБО ПКГ основну увагу приділяли усуненню шкідливого тиску фіксатора на кістку, багатоплощинній фіксації, взаємодії конструкції “пластина-гвинт”, забезпеченню МРВ, її регуляції, можливості індивідуального підбору найбільш оптимальної конструкції для конкретного перелому при мінімальному об'ємі і довжині імпланта. Враховуючи це, ми вдосконалили пристрій для фіксації кісткових відламків (ПФКВ) (патент України № 17502) (11), відповідно до анатомічних особливостей гомілки (рис. 1). Завдяки своїм конструктивним особливостям він усуває шкідливий тиск пластини на кістку.

Це, а також багатоплощинне проведення гвинтів, наявність елементу взаємодії “пластина-

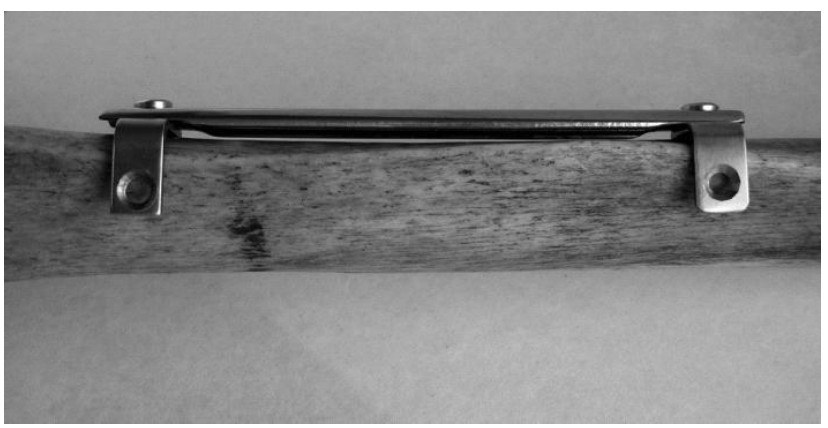

Рис. 1. Середня третина великогомілкової кістки із розміщеним на ній ПФКВ.

гвинт” може забезпечити надійну фіксацію фрагментів кісток гомілки при максимально можливій короткій пластині. Для зменшення об’єму ПФКВ товщина пластини по краях зменшена. Такі конструктивні зміни дають можливість зменшити об'єм фіксатора, що полегшує проблеми його встановлення і перекриття, дозволяє моделювати пластину для метаепіфізарних ділянок. Це особливо актуально для остеосинтезу дистального відділу великогомілкової кістки (ВГК). Фіксація півкілець, що моделюють фрагмент, до тоншої дистальної частини пластини дає можливість провести гвинти в сагітальному напрямі, це значно полегшує проведення операційного втручання.

Для зіставлення і правильної оцінки даних експериментальних досліджень із визначення мікрорухомості фрагментів, стабілізованих ПФКВ і повноконтактною НП, проведено теоретичні розрахунки з використанням методу кінцевих елементів (MKE).

Теоретичні та експериментальні дослідження величини МРВ залежно від способу фіксації проводили у Національному технічному університеті “Харківський політехнічний інститут (НТУ-ХПІ)” на кафедрі динаміки та міцності машин. На модель, що імітує зламану великогомілкову кістку (ВГК), при поперечному, косому, скалковому переломах були встановлені фіксатори, що досліджуються. Пластина ПФКВ лежить на 2 півкільцях, фіксацію фрагмента імітували проведенням 3-4 гвинтів у різних площинах через отвори пластини, півкілець і фрагмента. Повноконтактна НП умовно стабілізує фрагмент також 3-4 гвинтами. При косій лінії зламу, скалковому переломі фрагменти додатково стабілізували 1-2 репозиційними гвинтами.

Сітка із кінцевих елементів (рис. 2) допомагає проаналізувати ті переміщення відламків, які виникають при поперечній і косій лінії перелому. Для визначення напрямку дії сили на фіксований сегмент було використано Декартову систему координат, у якій вісь X збігалася з площиною пласти- 




Рис. 2. Десятивузловий тетраедральний кінцевий елемент.

ни, а вісь Y - спрямована перпендикулярно площині пластини.

Для числового розв'язання задачі на основі MKE про пружне деформування тримірного тіла створено об’ємні моделі, що відображають найбільш суттєві особливості геометрії ВГК, ПФКВ, контактної НП. 3 цією метою використано засоби твердотілого моделювання. Отримані моделі містять у спеціальному форматі повний опис геометрії і дають можливість виконати їхню дискретизацію шляхом розбиття на кінцеві елементи. Використання програмних засобів, що реалізують комплексні скінченноелементні розрахунки, дозволяє на стадії планування операції вибрати найбільш ефективну конструкцію відповідно до характеру перелому.

При дослідженні поперечного перелому в центральній частині ВГК осьовой зазор між торцевими поверхнями фрагментів у місці перелому становив 1,5 мм. Вивчали моделі стабілізації ПФКВ, контактної НП на фрагментах 3 і 4 гвинтами. Один із цих гвинтів, при фіксації ПФКВ, проводили через отвір півкільця.

При опрацюванні можливостей фіксаторів для остеосинтезу косих переломів вивчали три варіанти: а) фіксацію фрагмента 3 гвинтами; б) 4 гвинтами; в) фіксацію фрагментів після репозиції гвинтом, кінцеву стабілізацію фрагмента 3 гвинтами. Досліджували також МРВ при трьох варіантах фіксації скалкового перелому ВГК: а) фіксацію фрагмента 4 гвинтами; б) 4 фіксаційними гвинтами і одним репозиційним; в) 3 фіксаційними і двома репозиційними гвинтами.

Вивчали також напружений стан фіксаторів i кістки під дією доданого навантаження. Величина напруження елементів фіксатора і кістки свідчить про умови перебігу РР. Значне напруження фікса- тора і фрагментів не сприяє їх зрощенню. Інтенсивність напруг визначали за координатними компонентами відносних переміщень у відповідних точках перерізу ВГК.

Результати досліджень та їх обговорення. Доброго результату при ПКГ можна досягнути тільки після достатньої репозиції відламків, яка не супроводжується їх девіталізацією. Конструкція фіксатора повинна займати мінімальний об’єм, забезпечувати надійну фіксацію, можливість підбору найбільш оптимального варіанта для конкретного перелому.

Дуже важливим елементом у лікуванні ПКГ $є$ можливість програмувати жорсткість фіксації відповідно до характеру лінії перелому, можливість забезпечити певну величину МРB, що оптимізує перебіг РР. Одночасно ця мікрорухомість не повинна переходити у макропереміщення фрагментів під дією зовнішньої сили. Цьому протидіє багатоплощинна фіксація і елемент взаємодії “пластина-гвинт”. Застосування фіксатора не повинно посилювати травматизацію пошкодженого сегмента.

Поперечний перелом середньої третини ВГК є досить проблематичним для консолідації. Це пояснюється малою площею контакту між фрагментами при такій лінії перелому. В цій ситуації важливою для зрощення є наявність МРВ. Аналіз результатів комп’ютерного моделювання показав, що удосконалений нами ПФКВ допускає більші осьові переміщення фрагментів (0,0026-0,2903 мм) при осьовому навантаженні, ніж повноконтактна НП (0,0023-0,2395 мм). Необхідно відзначити невелику різницю величин МРВ в обох випадках. Звичайно, що повноконтактна НП забезпечує більш жорстку фіксацію фрагментів, це досягається шляхом притиснення пластини до кістки. Стабільність відламків ПФКВ досягається завдяки наявності елементу взаємодії “пластина-гвинт”, багатоплощинному проведенні гвинтів. Саме ці якості протидіють переходу МРВ у їх макропереміщення при лізисі кістки і навантаженні. Повноконтактна НП не протидіє такому переходу навіть при проведенні через фрагмент 4 кортикальних гвинтів. Разом із цим остеосинтез ПФКВ забезпечує менше напруження центральної частини кістки $\left(0,44017 \cdot 10^{7}\right.$ Па) навіть при фіксації фрагмента 3 гвинтами. Це створює оптимальні умови для перебігу РР.

Косий перелом ВГК є більш варіабельним порівняно із поперечним переломом. Велике значення у створенні оптимальних умов для консолідації має первинна стабілізація фрагментів репозиційними гвинтами - репозиційний остеосинтез (РО). 
Комп’ютерне моделювання показало значно менші показники МРВ ВГК (0,0019-0,0516 мм) при поєднанні РО і ПФКВ, ніж після кінцевої стабілізації повноконтактною НП (0,0041-0,0675 мм). Напруження пластини, шурупів, центральної частини кістки при фіксації репозиційним гвинтом і остеосинтезі ПФКВ значно менші $\left(0,11612 \cdot 10^{9}\right.$ Па), ніж у комбінації “репозиційний гвинт-повноконтактна НП” (0,13386•10 Па).

Дослідження показали, що при дії сили $100 \mathrm{H}$ на згин перпендикулярно площині пластини фіксація фрагментів 3-4 гвинтами, проведеними через повноконтактну НП без РО, допускає меншу МРВ. Остеосинтез косих переломів ПФКВ після попередньої стабілізації фрагментів репозиційним гвинтом забезпечує більш жорстку фіксацію при меншому напруженні пластини, гвинтів і центральної частини кістки. Аналогічні дані отримано при дії сили на згин у площині пластини. Це створює оптимальні умови для перебігу РР.

Слід відзначити, що після РО фрагментів гвинтами іноді досить проблематичним є встановлення поверх їх головок повноконтактної НП. Конструктивні особливості ПФКВ дозволяють усунути цей недолік.

У лікуванні скалкових переломів також велике значення має РО гвинтами. Саме тому в нашому дослідженні ми вивчали три варіанти фіксації: без репозиційного гвинта, з одним гвинтом, двома репозиційними гвинтами. Дослідження показали, що у всіх трьох варіантах при осьовому стисненні більш жорстку фіксацію забезпечує ПФКВ. Відмічено також зменшення МРВ після РО відламків одним і двома репозиційними гвинтами. Напруження пластини, гвинтів, центральної частини кістки після остеосинтезу ПФКВ є меншими порівняно з результатами, які дає використання повноконтактної НП.

ПФКВ допускає меншу, ніж контактна НП, МРВ при дії сили 100 Н на згин перпендикулярно площині пластини. Дослідження напруження фіксаторів і кістки показали, що у варіантах без репозиційного гвинта і з одним репозиційним гвинтом пластина ПФКВ є менш напруженою, при цьому основне напруження падає на кортикальні гвинти і центральну частину кістки.

Правильний і достатній РО відламків 2 кортикальними гвинтами зменшує ці напруження, створюючи оптимальні умови для зрощення кістки. Проте, на відміну від ПФКВ, встановлення повноконтактної НП поверх головок репозиційних гвинтів часто пов'язано із значними технічними труднощами. Багатоплощинне проведення гвинтів, наявність елементу взаємодії “пластина-гвинт” протидіє відходу пластини ПФКВ від кістки при лізисі кістки і навантаженні.

Тактика лікування ПКГ строго індивідуальна. Ïї розробляли із врахуванням отриманих результатів теоретичних досліджень МРВ, напружень елементів конструкції фіксаторів і кістки. Необхідно відзначити, що удосконалений нами ПФКВ досить простий у застосуванні, операційне втручання не потребує спеціального обладнання.

Успіх операційного лікування ПКГ визначається багатьма факторами. Серед них великого значення ми надаємо передопераційному плануванню. Обираючи тактику лікування ПКГ, ми враховували набутий досвід, результати комп'ютерних теоретичних біомеханічних досліджень із визначення величини МРВ для конкретної конструкції. Це позначалося на формуванні конструкції ПФКВ, визначало подальшу тактику. Так, при поперечній i косій лінії перелому стабільну фіксацію фрагментів забезпечує конструкція пристрою, де по краях пластини на 8 отворів зафіксовані півкільця (рис. 1). Стабільний остеосинтез гвинтоподібних і скалкових переломів може забезпечити пристрій із пластиною на 10-12 отворів.

Слід зазначити, що у всіх 90 потерпілих із ПКГ, оперованих ПФКВ, відмічено зрощення фрагментів. Сповільнення консолідації фрагментів відмічено у 8 випадках. Його відзначали після високоенергетичної травми, у пацієнтів із вираженим атеросклерозом судин нижніх кінцівок, при відсутності анатомічної репозиції фрагментів. Із 90 потерпілих віддалені результати у термін 8-16 місяців відслідковані у 84 хворих. Задовільні результати отримано у 5 (6\%) хворих, їхній стан оцінено у 11-8 балів. Критерієм для цього були суб’ єктивні й об’єктивні дані: незначний біль у кінцівці після фізичного навантаження, обмеження рухів у суміжних суглобах на 15-30 , сповільнена консолідація, незначне вторинне зміщення фрагментів, деяке обмеження працездатності. У решти 79 пацієнтів описані вище ознаки були відсутні, результат їхнього лікування визнаний добрим. Стан їх оцінено в 15-12 балів.

Висновки. Отримані нами результати досліджень величини МРВ, величини напружень конструкцій фіксаторів, центральної частини кістки підтверджують правильність розробленої нами концепції МБО ПКГ і дозволяють розробити ефективні методики їх застосування, які забезпечують добрий клінічний результат при діафізарних ПКГ, поліпшують якість життя пацієнтів, дозволяють позбутись багатьох ускладнень, характерних для традиційного остеосинтезу. 


\section{З ДОСВІДУ РОБОТИ}

\section{СПИСОК ЛІТЕРАТУРИ}

1. Білінський П. І. Теорія і практика малоконтактного багатоплощинного остеосинтезу / П. І. Білінський. - К. : Макрос, 2008. - 375 с.

2. Anglen J. Блокируемые пластины для переломов конечностей / J. Anglen, R. F. Kyle // Остеосинтез. - 2011. - № 1 (14). - C. 13-14 // JAAOS. - 2009. - Vol. 17, № 7. P. 647-657.

3. Влияние этиологического фактора травмы на течение репаративного остеогенеза. Часть 1. Сращение диафизарных переломов голени при непрямом механизме травмы / В. Г. Климовицкий, В. Н. Пастернак, В. М. Оксимец [и др.] // Травма. - 2007. - Т. 8, № 1. - С. 7-12.

4. Гончарова Л. Д. Концепция внутренних напряжений опорных структур и ее место в вопросах остеосинтеза / Л. Д. Гончарова, А. А. Тяжелов, Г. В. Лобанов // Травма. 2008. - Т. 9, № 2. - С. 227-231.

5. Динаміка регенерації кісткової тканини при множинних переломах кісток нижніх кінцівок з застосуванням блокуючого інтрамедулярного остеосинтезу / М. В. Гасько, А. Т. Зінченко, І. М. Циркот, І. В. Ковалишен // Травма. - 2008. - Т. 9, № 4. - С. 399-401.

6. Експериментально-біомеханічні випробування накісткового остеосинтезу при переломах діафіза великогомілкової кістки / М. Л. Анкін, Л. М. Анкін, М. С. Шидловський, М. М. Сатишев // Вісник ортопедії, травматології та протезування. - 2011. - № 1. - С. 68-73.

7. Концепция внутренних напряжений опорных структур и репаративный остеогенез : обзор литературы / A. M. Kuliev, V. G. Verdiev, N. T. Abdullaev, G. A. Aliev // Ортопедия и трав- матология Азербайджана. - 2010. - № 2. - С. 76-79.

8. Копитчак I. Р. Клініко-морфологічні особливості лікування переломів гомілки при політравмі : дис. ... канд. мед. наук : спец. 14.01.21 “Травматологія та ортопедія” / Ігор Романович Копитчак. - Тернопіль, 2011. - 163 с.

9. Купкенов Д. Э. Применение стержневых аппаратов при диафизарных переломах костей голени / Д. Э. Купкенов // Травматология и ортопедия России. - 2010. - № 2 (56). C. $39-44$.

10. Место и роль остеосинтеза в лечении повреждений опорнодвигательного аппарата при политравме / С. В. Рынденко, А. Г. Истомин, О. А. Попов [и др.] // Травма. - 2008. - Т. 6, № 1. - С. 99-102.

11. Патент № 17502 UA. МПК6 А 61 В 17/58, А 61 В 17/62. Пристрій для фіксації кісткових відламків / П. І. Білінський (UA) ; патентовласник П. І. Білінський (UA) ; № 96051961 ; заявл. 20.05.96. ; опубл. 31.10.97, Бюл. № 5. - 4 с.

12. Сименач Б. И. Фрактурология - некоторые аспекты теоретизации учения о переломах костей. Часть 2. Управление процессами репарации / Б. И. Сименач // Ортопедия, травматология и протезирование. - 2000. - № 4. - С. 105-117.

13. Современные представления об условиях консолидации переломов и возможность их обеспечения различными типами фиксаторов : обзор литературы / И. И. Мартель, Ф. А. Мацукатов, В. М. Шигарев, С. П. Бойчук // Гений ортопедии. - 2012. № 4. - С. 131-136.

14. Шимон В. М. Перспективні напрями лікування діафізарних переломів кісток гомілки / В. М. Шимон, А. А. Шерегій // Травма. - 2010. - Т. 11, № 4. - С. 363-366.

Отримано 15.07.15 